\title{
INTRINSIC FACTORS AFFECTING THE ACCEPTANCE OF MUSLIM SMALL ENTREPRENEURS IN KELANTAN TOWARDS AR-RAHNU
}

\author{
Salimah Yahaya* \\ Universiti Teknologi MARA
}

\begin{abstract}
Small entrepreneurs are often associated with the issue of difficulty in obtaining capital due to lack of trust from financial institutions. This is due to no loan repayment guarantee by small entrepreneurs. Therefore, ArRahnu is one of the alternatives to small entrepreneurs to get financing easily and quickly. However, response of Ar-Rahnu towards entrepreneurial goals is still low as a result of focusing more on personal use rather than for entrepreneurial purposes. Is this low response related to the low acceptance of Ar-Rahnu? Hence, this article intends to identify the intrinsic factors (internal stimuli) that affect the acceptance of Muslim small entrepreneurs in Kelantan towards Ar-Rahnu. A total of 350 respondents were selected by a purposeful sampling consisting of Muslim small entrepreneurs in Kelantan. The set of questionnaires consisted of 8 items relating to respondents' backgrounds, and 20 items on the intrinsic factors that affected the acceptance of small entrepreneurs towards Ar-Rahnu. The findings were analysed descriptively to analyse the percentage and mean values using Statistical Package for Social Sciences (SPSS) version 22.0. Overall, small entrepreneurs in Kelantan exhibited positive acceptance of Ar-Rahnu based on the intrinsic factors. This was indicated by the high mean value displayed by each item, particularly items for halal and haram considerations.
\end{abstract}

Keywords: Ar-Rahnu; Islamic pawn broking; Entrepreneurship; Kelantan; Behaviour; Acceptance.

Received: 3 April 2018

Accepted: 20 May 2020

\section{INTRODUCTION}

Ar-Rahnu is capable of being one of the micro credit schemes that helps low-income groups who are not eligible for funding from financial institutions. In addition, it also becomes an alternative to small entrepreneurs to seek capital financing for businesses (Noar \& Ahmad, 2015) as small entrepreneurs often face problems in obtaining funding from financial institutions (Sultana, Arifin, \& Juraini, 2015). These small-scale entrepreneurship activities include food stalls, tailors, handicraft shops, retail stores and so on. Most small entrepreneurs also have no collateral (land or house) or guarantor to get a loan. Financial institutions do not want to suffer losses because there is no guarantee of repayment due to the small-scale entrepreneurship activities (Al-Ameen, 2016). Therefore, Ar-Rahnu is one of the alternatives for small entrepreneurs to get funding, particularly for those who are marginalized by the formal financial system.

\footnotetext{
- Corresponding author: Salimah Yahaya, Academy of Contemporary Islamic Studies (ACIS), Universiti Teknologi Mara (UiTM) Cawangan Terengganu, Campus Dungun, 23000 Dungun, Terengganu, 013-4174267, email: salimahyahya@uitm.edu.my
} 
The main issue of acceptance of Ar-Rahnu by the small entrepreneurs is the weakness of service in micro credit institutions which causes difficulty for small entrepreneurs to get micro loan facilities (Mahmood \& Mohamad, 2011). Among them are bureaucratic red tape, stringent loan conditions, high leverage rates, requirements for collateral and guarantors, and overwhelming payment methods (Roslan \& Karim, 2009; Nor, 2011; Mohamad, Azer \& Che Harun@ Mohamad, 2013). In addition, the practice of riba by some micro credit institutions is clearly against the concept of business practiced in Islam. Another reason for the inefficient of current financing scheme is that it does not really help small entrepreneurs. Some of the terms and conditions cannot be fulfilled by these small entrepreneurs due to their small-scale businesses; thus, the financial institutions are not convinced that the loan can be paid within the period given without any guarantee.

Due to the difficulties to get loan from micro credit institutions, some entrepreneurs are unable to enlarge their businesses. Some of them also choose to get financial from illegal or not established financial institutions, while some may be obtained financial assistance from personal savings, siblings and relatives (Ibrahim, 2014). Insufficient capitals also hinder some entrepreneurs to continue and terminate their businesses. Therefore, it is observed that small entrepreneurs are greatly in need for financial assistance to ensure their business survival. Alternative ways should be provided to these small entrepreneurs in order to obtain faster and easier funding with low risk for their businesses growth. They should be encouraged to keep gold as savings which is more stable than money. Thus, it is important to study this issue to help small entrepreneurs to easily get financial from established institutions and prevent them from illegal finance institutions such as 'Ah-Long' (Bahari, Safii, Ahmad, Fisal, \& Shahar, 2015). Ar-Rahnu an established financing institutions with low risk, is perceived as an alternative medium for small entrepreneurs to obtain financial assistance for their businesses. Nevertheless, entrepreneurs are mostly not aware of its existence and benefits provided from this institution.

The weaknesses of micro credit institutions in providing funding to these small entrepreneurs have given opportunity to them to move to Ar-Rahnu which conforms to the principles of Islamic law, as well as provides easy and quick service (Hassan, Ahmad, \& Wahab, 2015). However, the acceptance of Ar-Rahnu by small entrepreneurs is still low because the use of Ar-Rahnu is more to bear personal cost of living rather than for the purpose of entrepreneurial activity (Azman, Kassim, \& Adeyemi, 2016). Cost of living defines daily necessities, payment of debt, medicine, education, traveling or purchasing a vehicle. Therefore, Ar-Rahnu is one of the institution that can prevent small entrepreneurs from selecting illegal or non-shariah compliance financial institutions with riba and high interest.

\section{LITERATURE REVIEW}

The reason for low response towards Ar-Rahnu is probably related to issues of public awareness and understanding. For the same reason, the response towards Ar-Rahnu is said to be lower than the conventional pawn (Sam, Tahir \& Latif, 2010). Conventional pawn becomes the user's choice over Ar-Rahnu due to misunderstanding of Ar-Rahnu's concept. A study by Hsni (2009) revealed that lack of knowledge of the local community in relation to Ar-Rahnu has become one of the factors that undermined the development of Ar-Rahnu. Therefore, Marimuthu, Lam, Chee, Razali, 
\& Kolandaisamy (2009) suggested promoting factor is essential to govern the understanding and knowledge of the people towards Ar-Rahnu.

In addition to the issue of understanding, Ar-Rahnu also faces issues related to halal and haram. As Muslims, consumers need to consider halal and haram when choosing a service. The halal and haram issues in Ar-Rahnu such as riba and Sharia compliance can lead to misunderstanding towards Ar-Rahnu (Azman, Kassim \& Adeyemi, 2016). In attracting multi-religious communities in Malaysia to accept Ar-Rahnu, Sharia compliance by Ar-Rahnu has no effect on their acceptance significantly (Hashim, Akir, \& Kamil 2013). Therefore, the study considered that the Sharia viewpoints cannot be a major factor in influencing the multi-religious communities to accept ArRahnu. The study by Hsni (2009) reported that the main factor of Muslim consumers to use ArRahnu is due to their awareness of riba. Amin, Chong, Dahlan and Supinah (2007) as well as Bhatt and Sinnakkannu (2008) stated Sharia-compliant Ar-Rahnu operations can attract the Muslim community to secure their valuable items for cash.

This article finds that previous studies also focused on discussing the extrinsic factors (external stimuli) rather than intrinsic factors (internal stimuli). For example, Magenderan, Wahid and Ahmad (2014) investigated the effectiveness of promotional factors and found that the Ar-Rahnu users in Selangor were more susceptible to electronic advertising than word-of-mouth promotions. In addition, Appannan and Doris (2011) and Muhamat, Rosly, \& Jaafar (2011) associated the extrinsic factors to good service factors that affected the Ar-Rahnu's acceptance. They acknowledged the comfort of Ar-Rahnu products as it is not necessary to disclose the reasons for performing pawn transaction due to confidentiality and security guarantee while using the ArRahnu service. Meanwhile, Marimuthu, Lam, Chee, Razali and Kolandaisamy (2009) assumed that the location of Ar-Rahnu branch which is only available in the city whereby most of its users live in the rural areas could be the drawback.

Hence, this article provides new insights when highlighting the intrinsic factors that have influenced the recent study on Ar-Rahnu regarding extrinsic factors. The intrinsic factor according to Hendriyanto (2012) originates from the inner self, while extrinsic factor comes from outside oneself. However, this article only focuses on the influence of intrinsic factors that have a direct relationship with religion such as the factors of maslahat returns and factor of use by priority that have been highlighted by Adnan (2010). The return of goodness or benefits means the law that has been approved and agreed by the Muslims and is closely related to the Sharia purposes (Mudjib \& Harisah, 1996). This includes banking transactions that maintain the benefits between debtors and creditors based on profit and loss sharing (Nasrudin \& Ismail, 2011). Meanwhile, as explained by Borhan (2008), use by priority is the expenditure of individual Muslim which is moderately done based on Sharia principles and restrictions. People tend to have different needs and desires and it makes it difficult to know the extent of an individual's use (Adnan, 2010). Based on previous studies, most researchers have merely focused on Ar-Rahnu consumers, but not to entrepreneurs as research respondents. This article is important to investigate entrepreneurs as respondents on the acceptance of small entrepreneurs towards Ar-Rahnu, whilst one of the main goals of Ar-Rahnu is to provide capital for entrepreneurial activities.

Therefore, the question is why the acceptance of small entrepreneurs toward Ar-Rahnu is still low? What are the real factors that determine the acceptance of small entrepreneurs towards Ar-Rahnu? Is it possibly due to intrinsic factors (individual internal stimulus such as halal and haram 
considerations, understanding, maslahat returns and use by priority)? Hence, a survey should be conducted on small entrepreneurs to know their acceptance of Ar-Rahnu which will influence their tendency to deal with Ar-Rahnu.

\section{METHODOLOGY}

Kelantan is one of the states in the East Coast of Peninsular Malaysia which has been selected as the location of the study influenced by several reasons. First of all, most people in Kelantan are actively involved in small business entrepreneurship and earn good income (Al-Mamun \& Ekpe, 2016). The Kelantan's are also known for their entrepreneurial capabilities admired by the Malays throughout the country (Nash, 2009 \& Yaacob, 2010). The selection of Kelantan as the study area was further confirmed by Yusoff and Yaacob (2010) that entrepreneurs in Kota Bharu Kelantan have made pawnshops as an alternative for capital sourcing. This is because most entrepreneurs especially women entrepreneurs keep and wear jewelleries. Likewise, Othman, Hashim and Abu Bakar (2009) reported that the culture of business among Kelantan's has contributed to the encouraging response to Ar-Rahnu in that state. Hence, there are two main questions identified in this article; first, what is the demographics background of Muslim small entrepreneurs in Kelantan? Second, what are the intrinsic factors that influence the acceptance of Muslim small entrepreneurs in Kelantan towards Ar-Rahnu?

In order to identify the intrinsic factors affecting the acceptance of small Muslim entrepreneurs in Kelantan towards Ar-Rahnu, 350 questionnaires were distributed to Muslim small entrepreneurs in Kelantan. According to Clark and Creswell (2015), 350 respondents are sufficient as minimum sample size needed in a questionnaire survey. The questionnaires were distributed at the main markets in ten districts of Kelantan. Small entrepreneurs that were selected in this study comprised small entrepreneurs with business capital starting from less than RM1,000 to not more than RM20,000 and capital starting from less than RM1,000 to not more than RM10,000.

Quantitative method was applied in this study. This study did not included the actual numbers of Muslim small entrepreneurs in Kelantan due to confidentiality from the markets management and availability of entrepreneurs at all time as they are mostly not consistent with their business operation hours. In fact, these small entrepreneurs have not normally registered their business due to the small-scale business activities which led to difficulty to identify the actual population of small entrepreneurs in Kelantan.

This article uses a purposive sampling method to obtain available information from individuals (Sekaran, 2003). Purposive sampling is limited to the specific types of people that can give information and 'most suitable' that can meet the purpose of research (Sekaran, 2006; Clark \& Creswell, 2015). The purposive sampling method was done by selecting small entrepreneurs as respondents who carried out a business near the Ar-Rahnu premises. All ten large markets were the main business areas located in the city and close to premises or branches of Ar-Rahnu. Therefore, most of the respondents already have information and familiar about Ar-Rahnu.

Questionnaire distributed to the respondents was in Malay language as the most used language among people in Kelantan. Each entrepreneur selected at the sampling location was approached and asked for permission to be respondent. Only Muslim small entrepreneurs were selected as 
respondents. After getting approval, each respondent was given a questionnaire to complete before submitting it back to the researcher. The findings were then analysed descriptively to find out the percentage and mean values using Statistical Package for Social Sciences (SPSS) version 22.0. The analysis of findings has been discussed in the next section which included the background of respondents' profiles, influence of intrinsic factors on the acceptance of Ar-Rahnu by Muslim small entrepreneurs in Kelantan, and conclusion.

\section{RESULTS AND DISCUSSION}

\subsection{Respondent's Profile and Background}

Demographic analysis was conducted on 350 small entrepreneurs. The characteristics of profile of the respondents were determined by descriptive statistics. Demographic profile of entrepreneurs was divided into gender, age, marital status, level of education and household income (monthly). The demographics profile of small entrepreneurs is shown in Table 1.

Table 1: Small Entrepreneurs Profile $(\mathrm{N}=350)$

\begin{tabular}{|c|c|c|c|}
\hline Num. & Entrepreneur Profile & Numbers & Percent (\%) \\
\hline \multirow[t]{4}{*}{1} & Gender & & \\
\hline & Male & 80 & 22.9 \\
\hline & Female & 270 & 77.1 \\
\hline & Total & 350 & 100.0 \\
\hline \multirow[t]{6}{*}{2} & Age & & \\
\hline & 18-29 years & 84 & 24.0 \\
\hline & $30-39$ years & 90 & 25.7 \\
\hline & $40-49$ years & 109 & 31.1 \\
\hline & 50 years and above & 67 & 19.1 \\
\hline & Total & 350 & 100.0 \\
\hline \multirow[t]{6}{*}{3} & Marital Status & & \\
\hline & Single & 62 & 17.7 \\
\hline & Married & 258 & 73.7 \\
\hline & Widower & 17 & 4.9 \\
\hline & Divorced & 13 & 3.7 \\
\hline & Total & 350 & 100.0 \\
\hline \multirow[t]{6}{*}{4} & Education Level & & \\
\hline & Primary School & 15 & 4.3 \\
\hline & Secondary School & 265 & 75.7 \\
\hline & Higher Education & 68 & 19.4 \\
\hline & Others & 2 & 0.6 \\
\hline & Total & 350 & 100.0 \\
\hline \multirow[t]{4}{*}{5} & Income & & \\
\hline & Less than RM1000 & 146 & 41.7 \\
\hline & RM1001-RM2000 & 114 & 32.6 \\
\hline & RM2001-RM3000 & 39 & 11.1 \\
\hline
\end{tabular}




\begin{tabular}{|c|c|c|c|}
\hline Num. & Entrepreneur Profile & Numbers & Percent (\%) \\
\hline & RM3001-RM4000 & 19 & 5.4 \\
\hline & RM4001-RM5000 & 13 & 3.7 \\
\hline & RM5001-RM6000 & 7 & 2.0 \\
\hline & More than RM6001 & 12 & 3.4 \\
\hline & Total & 350 & 100.0 \\
\hline \multirow[t]{11}{*}{6} & Type of Business & & \\
\hline & Food and beverages & 41 & 11.7 \\
\hline & Retail shop & 50 & 14.3 \\
\hline & Jewellery and flowers & 7 & 2.0 \\
\hline & Beauty and cosmetics & 21 & 6.0 \\
\hline & Fish and chick sellers & 27 & 7.7 \\
\hline & Fabric and clothing & 123 & 35.1 \\
\hline & Vegetables and fruits & 41 & 11.7 \\
\hline & Traditional Medicines & 3 & 0.9 \\
\hline & Others & 37 & 10.6 \\
\hline & Total & 350 & 100.0 \\
\hline \multirow[t]{7}{*}{7} & Duration of Business & & \\
\hline & 5 years and below & 105 & 30.0 \\
\hline & $6-10$ years & 92 & 26.3 \\
\hline & $11-15$ years & 49 & 14.0 \\
\hline & $16-20$ years & 45 & 12.9 \\
\hline & 21 years and above & 59 & 16.9 \\
\hline & Total & 350 & 100 \\
\hline \multirow[t]{13}{*}{8} & Business Capital & & \\
\hline & Less than RM1000 & 78 & 22.3 \\
\hline & RM1001-RM2000 & 55 & 15.7 \\
\hline & RM2001-RM3000 & 50 & 14.3 \\
\hline & RM3001-RM4000 & 29 & 8.3 \\
\hline & RM4001-RM5000 & 18 & 5.1 \\
\hline & RM5001-RM6000 & 37 & 10.6 \\
\hline & RM6001-RM7000 & 5 & 1.4 \\
\hline & RM7001-RM8000 & 6 & 1.7 \\
\hline & RM8001-RM9000 & 0 & 0 \\
\hline & RM9001-RM10,000 & 23 & 6.6 \\
\hline & More than RM10,001 & 49 & 14.0 \\
\hline & Total & 350 & 100.0 \\
\hline
\end{tabular}

Based on the findings in Table 1, most of the entrepreneurs involved in this distribution was female $(\mathrm{n}=270,77.1 \%)$ compared to male $(\mathrm{n}=80,22.9 \%)$. There was a significant difference between the female entrepreneurs and male entrepreneurs in the study area which proved that women are dominating the markets for small-scale business activities around Kelantan. Thus, women become a role model to the small entrepreneurship in Kelantan. This study also found many women traders in the market area compared to men. The involvement of women entrepreneurs in entrepreneurship also helps to generate additional income in their families (Yusoff \& Yaacob, 2010). It has been reported that entrepreneurial activity has long been in the Malay race in Kelantan, especially the 
women who are actively involved in entrepreneurship activities (Yusoff \& Yaacob, 2010; Azmi \& Ibrahim, 2013). Women in Kelantan particularly some who involved in business are normally kept gold are as savings. The gold's are usually purchased after obtaining profits from their business. Then, they go Ar-Rahnu branch and pawn the gold to get some money as capital for their business. Thus, women in Kelantan are playing significant roles for contribution in small entrepreneurship activities, and highly accepting the Ar-Rahnu as their alternative financial institution.

In terms of age, majority of entrepreneurs were between 40 and 49 years old $(n=109,31.1 \%)$, followed by entrepreneurs aged between 30 to 39 years $(n=90,25.7 \%)$, younger group aged between 18 and 29 years old $(n=84,24 \%)$, and entrepreneurs who aged over 50 years old $(n=$ $67 \%, 19.1 \%$ ). At the age of 40 to 49 years, the community tends to be more competitive. They are willing to risk their involvement in entrepreneurship since they have life experience. At this level of age, some of them chose to engage in entrepreneurship after retiring from previous jobs such as government pensioners. These findings also provided information that people of Kelantan have high interest and ability to do business at all ages whether young or adult.

In terms of marital status, the majority of entrepreneurs were married $(\mathrm{n}=258,73.7 \%)$, while the rest were single $(\mathrm{n}=62,17.7 \%)$, widowed $(\mathrm{n}=17,4.9 \%)$ and divorced $(\mathrm{n}=13,3.7 \%)$. The entrepreneurial groups for married and single status showed a very significant difference. This finding reflected that the married group managed their business for their own family needs as a mature population. It can be assumed that married people have self-reliant attitude by trying to earn incomes through business compared to entrepreneurs with single status who mostly were more comfortable to be employees.

In addition, the majority of entrepreneurs received education at secondary level $(\mathrm{n}=265,75.7 \%)$, followed by certificates, diplomas and degrees holders $(n=68,19.4 \%)$, education at primary level $(\mathrm{n}=14,4.0 \%)$, and the remaining has not received formal education from any institution $(\mathrm{n}=2$, $0.6 \%$ ). Generally, most of the entrepreneurs did not pursue their studies at higher level and chose to be involved in entrepreneurship that does not require high skills.

For income earning, the number of respondents who earned less than RM1000 was the highest (n $=146,41.7 \%)$. Then, followed by respondents who earned between RM1001 to RM2000 $(n=114$, $32.6 \%)$. About 39 respondents earned income of RM2001 to RM3000 $(n=39,11.1 \%)$. Hence, the majority of respondents have income less than RM1000 which indicated that the income earned through business was not so high as the respondents only run small businesses with small capital. The earning of small entrepreneurs was also small due to the small capital invested.

The majority of entrepreneurs was found to involve in the fabric and clothing business ( $\mathrm{n}=122$, $34.9 \%$ ), followed by retail shops ( $\mathrm{n}=50,14.3 \%$ ), food and beverages business and vegetables and fruits business $(n=41,11.7 \%)$. The rest involved in other businesses $(n=38,10.9 \%)$ which included shoe and slippers, bags, spices, kitchen utensils, rice, gold trade and so on. These statistics illustrated the diversity of businesses undertaken by the respondents at the main markets in Kelantan. However, apparel and clothing business was dominant around the markets in every district in Kelantan.

Additionally, 105 entrepreneurs (30\%) involved in the business for 5 years and below, whilst 93 entrepreneurs $(26.3 \%)$ run their business within 6 to 10 years. The rest of the entrepreneurs mostly 
engaged in business over 21 years $(n=59,16.9 \%)$. The duration of involvement in carrying out business showed that most entrepreneurs were still new to entrepreneurship and generated various business experiences.

In terms of total business capital obtained, most respondents used capital of less than RM1000 (n $=78,22.3 \%)$, and within the range of RM1001 to RM2000 $(\mathrm{n}=55,15.7 \%)$. In addition, some respondents used business capital of more than RM10,001 ( $\mathrm{n}=49,14.0 \%)$. The use of capital above RM10,001 was probably involving respondents in fabric and clothing business that required a larger amount of capital compared to other businesses in this small entrepreneurial category. Overall, entrepreneurs in this small-scale entrepreneurial category have issued capital starting from less than RM1000, but not more than RM20,000.

The results of the respondents' demographic statistics can be summarized that the majority of respondents were women, adults (40s), married, received education at secondary school level, earning less than RM1,000 and a capital of less than RM1000. Additionally, the majority of respondents are engaged in fabric and clothing business with new business experience.

The diversity of respondents' backgrounds from various demographic characteristics has resulted in various acceptance factors of the respondents towards Ar-Rahnu. Feedback received from the respondents is important information in order to know more about the intrinsic factors that affected the acceptance of Muslim small entrepreneurs in Kelantan towards Ar-Rahnu.

\subsection{The Influence of Intrinsic Factors towards Ar-Rahnu Acceptance of Muslim Small Entrepreneurs in Kelantan.}

To measure the intrinsic factors affecting the acceptance of respondents, the 5-point Likert Scale was used in this study to assess the level of acceptance of small entrepreneurs towards Ar-Rahnu.

Table 1: Research Scale

\begin{tabular}{ccc}
\hline Meanings & Scale & Perception Interpretation \\
\hline Strongly Disagree & 1 & Negative perception \\
Disagree & 2 & \\
Neutral & 3 & Uncertain perception \\
Agree & 4 & \\
Strongly Agree & 5 & Positive perception \\
\hline \hline
\end{tabular}

Based on Table 1, 5 scales were used. Scale 1 and 2 represented the negative perceptions of respondents about their acceptance towards Ar-Rahnu. Scale 3 represented uncertain perception, while scale 4 and 5 represented positive perception towards Ar-Rahnu. Perception interpretation level for mean value is also shown in Table 3. 
Table 2: Perception Interpretation and Mean Value

\begin{tabular}{cc}
\hline \hline Mean Value & Perception Interpretation \\
\hline 1.0 to 2.49 & Low \\
2.5 to 3.49 & Moderate \\
3.5 to 5.00 & High \\
\hline \hline
\end{tabular}

Table 2 shows the relationship between mean value and interpretation of respondents' perceptions. Perception interpretation was at low level indicated by the mean value of 1.00 to 2.49 , while the mean value was at moderate level represented by a mean value of 2.5 to 3.49 . High and good perception was indicated by a mean value between 3.5 and 5.00 .

Table 4: Summary of Findings on Intrinsic Factors Influencing the Acceptance of Muslim Small Entrepreneurs in Kelantan towards Ar-Rahnu

\begin{tabular}{|c|c|c|c|c|c|}
\hline Num. & Statement & $\begin{array}{l}\text { Negative } \\
\text { Perception } \\
(\%) \\
\end{array}$ & $\begin{array}{l}\text { Uncertain } \\
\text { Perception } \\
(\%) \\
\end{array}$ & $\begin{array}{c}\text { Positive } \\
\text { Perception } \\
(\%) \\
\end{array}$ & Mean \\
\hline & \multicolumn{5}{|l|}{$\begin{array}{l}\text { Consideration of Halal and Haram } \\
\text { (4 items) }\end{array}$} \\
\hline 1 & $\begin{array}{l}\text { I choose Ar-Rahnu to take care of my } \\
\text { relationship with Allah SWT }\end{array}$ & 16.9 & 20.3 & 62.8 & 3.65 \\
\hline 2 & $\begin{array}{l}\text { As a Muslim, I must choose Ar-Rahnu } \\
\text { compared to the conventional pawn }\end{array}$ & 8.6 & 15.1 & 76.3 & 3.98 \\
\hline 3 & $\begin{array}{l}\text { If I need to be in debt, I still choose Ar-Rahnu } \\
\text { although it is even more expensive than the } \\
\text { conventional pawn }\end{array}$ & 16.0 & 21.4 & 62.6 & 3.65 \\
\hline 4 & $\begin{array}{l}\text { I reject the loaning facilities on business that } \\
\text { raises suspicion, especially in terms of its } \\
\text { halal nature }\end{array}$ & 10.3 & 17.7 & 72.0 & 3.89 \\
\hline & $\begin{array}{l}\text { Understanding towards Ar-Rahnu (6 } \\
\text { items) }\end{array}$ & & & & \\
\hline 5 & $\begin{array}{l}\text { I obtain complete information about Ar- } \\
\text { Rahnu }\end{array}$ & 15.2 & 32.3 & 52.5 & 3.48 \\
\hline 6 & $\begin{array}{l}\text { I know the difference between Ar-Rahnu and } \\
\text { conventional pawnshops }\end{array}$ & 11.7 & 24.3 & 64.0 & 3.68 \\
\hline 7 & $\begin{array}{l}\text { I know that there is the concept of helping } \\
\text { each other in Ar-Rahnu }\end{array}$ & 9.7 & 19.1 & 71.1 & 3.79 \\
\hline 8 & $\begin{array}{l}\text { I know Ar-Rahnu does not contradict Islamic } \\
\text { principles }\end{array}$ & 6.8 & 14.6 & 78.5 & 4.00 \\
\hline 9 & $\begin{array}{l}\text { I know that Ar-Rahnu is free from the } \\
\text { elements of riba }\end{array}$ & 7.7 & 18.6 & 73.8 & 3.93 \\
\hline 10 & $\begin{array}{l}\text { I have knowledge about the sharia principles, } \\
\text { namely Qard al-Hasan, al-Wadiah, al-Rahn } \\
\text { and Ujrah contained in Ar-Rahnu }\end{array}$ & 13.4 & 37.1 & 49.5 & 3.47 \\
\hline
\end{tabular}




\begin{tabular}{|c|c|c|c|c|c|}
\hline Num. & Statement & $\begin{array}{l}\text { Negative } \\
\text { Perception } \\
\quad(\%) \\
\end{array}$ & $\begin{array}{l}\text { Uncertain } \\
\text { Perception } \\
\quad(\%) \\
\end{array}$ & $\begin{array}{l}\text { Positive } \\
\text { Perception } \\
\text { (\%) } \\
\end{array}$ & Mean \\
\hline \multicolumn{6}{|c|}{ Maslahat Returns (6 items) } \\
\hline 11 & $\begin{array}{l}\text { By choosing Ar-Rahnu, I will obtain a good } \\
\text { profit for my worldly affairs and rewards in } \\
\text { the Here after }\end{array}$ & 10.6 & 23.7 & 65.7 & 3.74 \\
\hline 12 & $\begin{array}{l}\text { I realize that there are bad impacts from Ar- } \\
\text { Rahnu that practises riba }\end{array}$ & 20.0 & 19.4 & 60.5 & 3.53 \\
\hline 13 & $\begin{array}{l}\text { I believe that Ar-Rahnu promises a share of } \\
\text { profit to the lenders and borrowers }\end{array}$ & 14.3 & 30.6 & 55.1 & 3.50 \\
\hline 14 & $\begin{array}{l}\text { I believe that Ar-Rahnu promises the share of } \\
\text { loss to lenders and borrowers }\end{array}$ & 30.5 & 31.7 & 37.7 & 3.08 \\
\hline 15 & $\begin{array}{l}\text { I believe that Ar-Rahnu practices the } \\
\text { principle of joint fairness between the lender } \\
\text { and borrower }\end{array}$ & 8.6 & 20.9 & 70.5 & 3.75 \\
\hline \multirow{2}{*}{16} & $\begin{array}{l}\text { My participation in Ar-Rahnu can help } \\
\text { contribute to the Muslims' economic } \\
\text { development. }\end{array}$ & 8.3 & 21.7 & 70.0 & 3.79 \\
\hline & Use by Priority ( 4 items) & & & & \\
\hline 17 & $\begin{array}{l}\text { I believe that leaving riba is more important } \\
\text { than performing non-obligatory worship }\end{array}$ & 7.7 & 18.9 & 73.5 & 3.91 \\
\hline 18 & $\begin{array}{l}\text { I believe that Ar-Rahnu can give benefit to } \\
\text { the people compared to individuals }\end{array}$ & 13.1 & 24.6 & 62.3 & 3.63 \\
\hline 19 & $\begin{array}{l}\text { I prioritise Ar-Rahnu which is free from } \\
\text { syubhah compared to the conventional pawn } \\
\text { that has elements of syubhah }\end{array}$ & 8.3 & 20.9 & 70.9 & 3.81 \\
\hline 20 & $\begin{array}{l}\text { I prioritise the conventional financing priority } \\
\text { in some circumstances }\end{array}$ & 29.2 & 33.7 & 37.1 & 3.09 \\
\hline
\end{tabular}

Average Mean Overall=3.67

Based on Table 4, there were four determinants of intrinsic factors, namely halal and haram considerations, understanding of Ar-Rahnu, Maslahat returns (return of benefits) and use by priority. The four factors included twenty items which were used to review the acceptance of ArRahnu by Muslim small entrepreneurs in Kelantan. The findings showed that most respondents agreed on the items indicated by the high mean value of each item. The item that recorded the highest mean value was related to the understanding of Ar-Rahnu factor, i.e. "I know Ar-Rahnu does not contradict with Islamic principles" with a mean value of 4.00 . About $78.5 \%$ agreed and strongly agreed that Ar-Rahnu complied with Islamic Sharia in its implementation. Item that recorded the second-highest value was halal and haram considerations, i.e. "As a Muslim, I must choose Ar-Rahnu compare to conventional pawnshops" with a mean value of 3.98. Additionally, item that showed the third-highest mean value was related to the understanding of Ar-Rahnu factor, i.e. "I know that Ar-Rahnu is free from the element of riba" with a mean value of 3.93. Next, use by priority factor recorded a mean value of 3.91, i.e. "I believe that leaving riba is more important than performing non-obligatory worship". 
The findings concluded that the majority of Muslim small entrepreneurs in Kelantan understood that Ar-Rahnu is a Sharia-compliant Islamic financing scheme and does not practice riba in the provision of its services, as well as believed that it is important to stay away from practicing riba in life. The findings were consistent with previous studies from Tahar (2001), Salleh (2005) and Baharum (2014) who agreed that Ar-Rahnu which was implemented in several institutions in Malaysia has no conflict with Islamic Sharia. In addition, according to Yusof (2004), customers have high trust and confidence in Ar-Rahnu due to its compliance with the operation of Islamic law, for instance no usury, oppression and fraud in its affairs.

The findings also found that all items recorded a high mean value of 3.5 to 5.00 . However, there were 4 items that recorded a medium mean value, i.e. items of $5,10,14$ and 20 . The item that recorded the lowest mean value was for the maslahat returns factor, i.e. "I believe that Ar-Rahnu promises a share of profit to the lenders and borrowers" with the mean value of 3.08 . About $30.5 \%$ of respondents showed negative perception, while $31.7 \%$ of respondents showed uncertain perception for this item. Additionally, item of use by priority factor, i.e. "I prioritize the conventional financing priority in some circumstances" recorded the lowest mean value of 3.09. About $29.2 \%$ of respondents disagreed, while $33.7 \%$ showed uncertain answers to this item. These responses highlighted that the respondents still choose Sharia-compliant financing.

In addition, there were two items from the understanding toward Ar-Rahnu factor which also showed a mean value at a moderate level of 3.48 for the items of "I get complete information about Ar-Rahnu" and "I have knowledge about Sharia principles, namely Qard al-Hasan, al-Wadiah, alRahn and Ujrah contained in Ar-Rahnu" with a mean value of 3.47. This finding showed that the respondents did not receive enough information about Ar-Rahnu, particularly the implementation of Sharia principles in the Ar-Rahnu. The findings were in line with a study by Hsni (2009) who found that lack of knowledge of the local community has hampered the development of Ar-Rahnu. It is therefore important for the community to understand the Ar-Rahnu procedure so that no misunderstanding will occur to these Islamic financial instruments. According to Azman (2010), the misunderstanding of Ar-Rahnu occurs when there are entrepreneurs who think that the storage wages charged by Ar-Rahnu are similar to riba as applied by the conventional pawn concept.

Based on the findings, the overall mean of all the items obtained was 3.67. This indicated that the respondents gave positive responses as well as clarifying that the proposed items have reinforced the factors affecting their acceptance towards Ar-Rahnu. The findings also showed that the acceptance of Ar-Rahnu by small entrepreneurs was largely driven by individual internal factors. As a result, halal and haram considerations dimensions have recorded the highest mean value compared to other factors in the intrinsic constructs. It was supported by the findings from Hamid, Rahman, \& Halim (2014) which stated that the Ar-Rahnu Sharia factor which was to reject the haram and to choose halal recorded the highest mean score and became the main criteria in choosing Ar-Rahnu.

\section{CONCLUSION}

It can be concluded from the findings that the intrinsic factors and internal stimuli are very important in influencing the acceptance of Muslim small entrepreneurs towards Ar-Rahnu owing to high mean values which were related to usury and compliance with Islamic sharia. The findings 
also highlighted the dominance of all religious factors, particularly halal and haram considerations either directly or indirectly. However, there were 4 items that showed moderate level of mean value for items of understanding towards Ar-Rahnu. These findings also suggested that although small entrepreneurs show their trust in Ar-Rahnu's compliance with Islamic Sharia, however, small entrepreneurs still do not get the correct information about Ar-Rahnu. This study is expected to contribute and help Ar-Rahnu institution to improve its service level and marketing. The outcome of this study can provide important information to the institution to provide more effective marketing strategy and to follow the Islamic sharia as guidelines. This study can give positive change the perception to small entrepreneurs about the benefits of Ar-Rahnu and the difference between Ar-Rahnu and conventional pawnshop.

\section{REFERENCES}

Adnan, A. A. (2010). Penentu pemilihan institusi perbankan Islam dalam kalangan Muslim di Terengganu (Doctoral thesis, Universiti Sains Malaysia, Pulau Pinang, Malaysia).

Al-Ameen, A. (2016). Implementing Islamic microfinance in Nigeria: A matter of equity and social justice. Journal of Sustainable, Development, Law and Policy, 7(2), 211-246.

Al-Mamun, A., \& Ekpe, I. (2016). Entrepreneurial traits and micro-enterprise performance: Study among women micro entrepreneurs in Malaysia. Development in Practice, 26(2), 193202.

Amin, H., Chong, R., Dahlan, H., \& Supinah, R. (2007). An Ar-Rahnu shop acceptance model (ARSAM). Labuan e-Journal of Muamalat and Society, 1(2007), 82-94.

Appannan, S., \& Doris, G. (2011). A study on Islamic pawn broking awareness and factors influencing the scheme in Sungai Petani, Kedah. Proceedings of the $2^{\text {nd }}$ International Conference on Business and Economic Research (2nd ICBER 2011).

Azman, N. H. N. (2010). Acceptance of Ar-Rahnu in Kelantan: Evidence from Pasar Besar Khadijah. Paper presented at the 5th ISDEV International Graduate Workshop (INGRAW 2010), University Conference Hall, Universiti Sains Malaysia, Pulau Pinang, Malaysia.

Azman, N. H. N., Kassim, S., \& Adeyemi, A. A. (2016). Role of Ar-Rahnu as micro credit instrument in achieving financial self-sufficiency among women micro entrepreneurs. Islamic International University Malaysia (IIUM) Journal, 24(2018), 36-385.

Azmi, I. A. G., \& Ibrahim, M. D. (2013). Wanita dan pelaksanaan amalan keusahawanan Islam: Satu kerangka konseptual. Proceedings of the International Conference on Islamic Management, Department of Sharia and Management, Islamic Studies Academy, Universiti Malaya, Kuala Lumpur.

Bahari, N. F., Safii, Z., Ahmad, N. W., Fisal, S., \& Shahar, W. S. S. (2015). A reviews on the regulation and conflicting issues of Ar-Rahnu operation in Malaysia. Proceedings of the 2nd International Conference on Management and Muamalah.

Baharum, N. N. (2014). Factors of customer's intention to use ar-rahnu at post office: A case study in Kedah (Master Thesis, Universiti Utara Malaysia, Kedah, Malaysia).

Bhatt, P., \& Sinnakkannu, J. (2008). Ar-Rahnu (Islamic pawning broking) opportunities and challenges in Malaysia. Proceedings of the 6th International Islamic Finance Conference 2008, Malaysia

Borhan, J. T. (2008). Pemikiran pembangunan ekonomi berteraskan Islam. Jurnal Usuluddin, 27(2008), 93-107. 
Clark, V. L. P., \& Creswell, J. W. (2015). Understanding research: A consumer's guide. New Jersey: Pearson Education.

Hamid, M. A., Rahman, I. A., \& Halim, A. N. A. (2014). Factors affecting the acceptance on ArRahnu (Islamic based pawn broking): A case study of Islamic banking in Malaysia. The Macrotheme Review: A Multidisciplinary Journal of Global Macro Trends, 3(4), 22-35.

Hashim, N., Akir, O., \& Kamil, D. (2013). Customers' acceptance of Islamic pawn broking service in Sarawak. Proceedings of the International Conference Islam Borneo VI (KAIB 2013), UiTM Sarawak.

Hassan, F. S., Ahmad, S., \& Wahab, H. (2015). Penerimaan Masyarakat terhadap skim gadaian Islam di Kota Bharu Kelantan. Proceedings of the Seminar Fiqh Semasa (SeFIS). Sepang: Usuli Faqih Research Centre, Malaysia.

Hendriyanto, A. (2012). Pengaruh motivasi intrinsik dan ekstrinsik terhadap kinerja karyawan studi pada Perum Surabaya Selatan (Master Thesis, Universiti Brawijaya, Indonesia).

Hsni, E. N. T. (2009). Faktor-faktor yang menentukan sambutan pengguna terhadap skim pajak gadai Islam dan konvensional dalam kalangan orang Islam Seberang Perai (Master Dissertation, Universiti Sains Malaysia, Pulau Pinang, Malaysia).

Ibrahim, Y. (2014). Keusahawanan dan daya saing dalam sektor pelancongan pulau. UNISZA, Terengganu: Penerbit Universiti Sultan Zainal Abidin.

Mahmood, R., \& Mohamad. M. R. (2011). Perusahaan kecil dan dilema usahawan Melayu. Universiti Malaya, Kuala Lumpur: Penerbit Universiti Malaya.

Magenderan, M., Wahid, H., \& Ahmad, S. (2014). Keberkesanan medium promosi Skim Ar-Rahnu di kedai Ar-Rahnu, Bank Rakyat: Kajian kes di Bandar Sri Permaisuri, Cheras. Proceedings of International Conference Muamalat, Economics and Islamic Finance, Institut Latihan Islam Malaysia, Bangi, Selangor, 238-255.

Marimuthu, M., Lam, H. Y., Chee, C. Y., Razali, H., \& Kolandaisamy, I. (2009). Islamic pawning (Ar-Rahnu) and factor affecting customer's switching behavior: An exploratory study. Paper Presented at The 3rd ISDEV International Islamic Development Management Conference (IDMAC2009): Islamic Capital Market, University Conference Hall, Universiti Sains Malaysia, Pulau Pinang, Malaysia.

Mohamad, S. A., Azer, I., \& Che Harun@Mohamad, M. F. A. A. (2013). Small business owners' response towards patronage of Islamic Pawn Broking service in Pahang. Proceedings at the Islamic Perspective on Management Contemporary Issues, YaPEIM Management Academy and Academy of Islamic Studies.

Mudjib, A. N., \& Harisah, A. (1996). Maslahat, antara syari'ah dan filsafat. Retrieved from http://pcinu-mesir.tripod.com/ilmiah/jurnal/isjurnal/ nuansa/Jan96/2.htm

Muhamat, A. A., Rosly, H. E., \& Jaafar, M. N. (2011). The Non-muslims response towards ArRahnu (Islamic Pawn Broking) services: An empirical study on the Ar-Rahnu clients of Klang Valley, Malaysia. Proceeding of the 2011 IEEE Colloquium on Humanities, Science and Engineering.

Nash, M. (2009). The market as arena for change in Kelantan, Malaysia. American Anthropologist, 70(5), 944-949.

Nasrudin, W. F. A. W., \& Ismail, M. A. (2011). Hubungan perbankan dalam perbankan Islam. Proceedings at the Persidangan Kebangsaan Ekonomi Malaysia ke VI (PERKEM VI), Melaka Bandaraya Bersejarah.

Noar, Z. M., \& Ahmad, N. L. (2015). The effectiveness of Al-Rahn (Islamic pawn broking scheme) on socio economic needs: A case study in Kuantan and Kuala Terengganu, Malaysia. Revelation and Science, 5(2), 14-23. 
Nor, A. M. (2011). Keberkesanan skim pinjaman Tekun Nasional terhadap perkembangan perusahaan kecil dan sederhana (PKS): Satu kajian di Daerah Yan, Kedah (Master Dissertation, Universiti Utara Malaysia, Kedah, Malaysia).

Othman, A., Hashim, N., \& Bakar, A. B. (2009). Pengurusan Gadaian Menurut Islam: Kajian di Kedai Ar-Rahn Kelantan. Proceeding of the International Conference on Corporate Laws, Surabaya, Indonesia.

Roslan, A. H. \& Karim, M. Z. A. (2009). Determinants of microcredit repayment in Malaysia: The case of Agro Bank. Humanity and Social Sciences Journal, 4(1), 45-52.

Salleh, S. (2005). Sistem Gadaian Islam: Pengamalan dan keberkesanan operasinya di Negeri Perlis (Master Dissertation, Universiti Malaya, Kuala Lumpur, Malaysia).

Sam, M. F. M., Tahir, M. N. H., \& Latif, N. K. A. (2010). The awareness and the acceptance of Islamic pawnshop. International Journal of Research and Reviews in Applied Sciences (IJRRAS), 2(2), 117-125.

Sultana A. M., Arifin N. S., \& Juraini, J. O. (2015). Women involvement in small-scale business in Kota Bharu, Kelantan, Malaysia. Proceedings of the $8^{\text {th }}$ Asia-Pacific Business Research Conference, Hotel Istana, Kuala Lumpur.

Tahar, A. S. (2001). Pelaksanaan Skim Gadaian Islam: Kajian di Muassasah Gadaian Islam Terengganu (Master Dissertation, Universiti Kebangsaan Malaysia, Bangi, Selangor, Malaysia.

Yaacob, M. R. (2010). A preliminary study of green micro-entrepreneur in Kelantan, Malaysia. International Journal of Business and Management, 5(3), 81-88.

Yusof, S. M. (2004). Persepsi pelanggan Islam terhadap perkhidmatan pajak gadai Islam di ArRahnu, Koperasi Pegawai-pegawai Kerajaan Negeri Kedah Darul Aman Berhad (Research Report, Universiti Utara Malaysia, Kedah, Malaysia).

Yusoff, M. N. H., \& Yaacob, M. R. (2010). Kajian awalan perbandingan aktiviti keusahawanan antara Kota Bharu Kelantan dan Padang, Sumatera. Proceedings of the Persidangan Kebangsaan Ekonomi Malaysia ke V (PERKEM V), Inovasi dan Pertumbuhan Ekonomi, Port Dickson, Negeri Sembilan. 